\title{
An Investigation of Kagera River Basin Land Cover Dynamics for Sustainability of Lake Victoria Water Regime
}

\author{
M. Hagai ${ }^{1}$ \\ ${ }^{1}$ School of Earth Sciences, Real State, Business and Informatics-Department of Geospatial Sciences and \\ Technology, Ardhi University, Tanzania \\ Correspondence: M. Hagai, School of Earth Sciences, Real State, Business and Informatics-Department of \\ Geospatial Sciences and Technology, Ardhi University, P.O. Box 35176 Dar es Salaam, Tanzania. Tel: \\ 255-6-5549-4985. E-mail: martinehagai@gmail.com
}

Received: April 15, 2019

doi:10.5539/jsd.v12n4p166
Accepted: June 22, $2019 \quad$ Online Published: July 30, 2019

URL: https://doi.org/10.5539/jsd.v12n4p166

\begin{abstract}
This paper is reporting on an investigation done to assess land cover dynamics in KRB(Kagera River Basin) (KRB) over a period of 21 years i.e.1990-2011 using Remote Sensing, Hydrology and GIS techniques as a basis for initiating policy interventions for sustainability of Lake Victoria water regime.The extent of land cover changes in the KRB have not been quantified with the view of assessing the extent of exploitation of the natural resources. The assessment is important firstly for identification of causative factors and secondly as a mechanism for formulating necessary policies and remedial measures to that effect.Specifically, Landsat 5, Landsat 7 and ETM+ (2000) satellite images were used.Eight Land Cover classes were identified namely, Forests, Woodland, Bushland, Cultivated Land, Swamps, Grassland, Bareland and Urban areas.Hydrographical data were used to assess changes in quantity of water flowing from the KRB into Lake Victoria and relating it with land cover changes in KRB at in the period of study. Spatial data processing, analysis and interpretation were carried out in ERDAS Imagine and ArcGIS software environments; while water quantity data and other non spatial data were processed and analyzed in Microsoft Excel application 2007.

The study revealed a significant decline of vegetation cover and water quantity discharged from Kagera River to Lake Victoria over the study period. This contravenes the global efforts of ecological sustainability, which urge avoidance of depletion of natural resources for maintenance for ecological balance. These results are in early warning to the Management of Lake Victoria for its potential failure towards achieving the Millennium Development Goal on responsible consumption and protection of natural resources in proximity with Lake Victoria. The Management of Lake Victoria in collaboration with other relevant authorities should thus, take remedial measures to control further depletion of vegetation cover in KRB for sustainability of Lake Victoria and its ecosystem.
\end{abstract}

Keywords: Kagera River Basin, Lake Victoria, land cover, change detection, remote sensing and geographic information system

\section{Introduction}

The Kagera River Basin (KRB), located in North-Western Tanzania has been experiencing land use and land cover changes mainly due to anthropogenic activities over the years, while hosting Kagera River. Natural resources in the proximity of the Kagera River, which begins from Burundi flowing through Rwanda, Uganda and Tanzania into Lake Victoria, has been affected leading to unsustainable land use and management practices. Maintenance of the Kagera water flow regime is vital for sustainability of Lake Victoria water level.

Anthropogenic alterations of the natural landscape through urbanization, agriculture and forestry have increased for the past millennium. In the process, land cover has been removed and replaced with the human managed systems on altered landscape structure.Due to socio -economic activities, land cover have drastically changed in the tropics.This has resulted in adverse effects on physical and ecological process, as well as on soil and water and biodiversity.Recently, efforts have been made to quantify the nature and extent of land cover changes including vegetation at global scale which estimated that over the last 300 years, the total global area of forest and woodland diminished by $19 \%$, while grasslands increased by $47 \%$. 
Most of the landscapes on the Earth's surface have significantly been altered by humans. Mankind's modification of the landscape has had a profound effect (both positive and negative) upon the natural environment These anthropogenic influences on shifting patterns of land cover changes have influenced the many current environmental concerns. Land use and land cover change have now gained recognition as being a driver of environmental change. These changes have become pervasive, increasingly rapid, and continue to have adverse impacts and implications at local, regional and global scales.

Over the years, man has become the major and most powerful threat to environmental change in the biosphere today. Land cover today is altered mainly by direct human use, indeed this is fueled by population increase global climatic changes, policy changes and so on.

To better understand the impact of land cover/use change on terrestrial ecosystems, the factors affecting land use need to be fully examined. It is noteworthy that land cover change practices evolve over long periods of time under different environmental, political, demographic, and social conditions.

It is noteworthy that changes in land cover changes result in significant hydrologic changes. For example, removal of forest covers resulting into decreased interception, evapotranspiration and increased runoff volumes. Research has shown that tree canopy can intercept $10-40 \%$ of incoming precipitation (commonly 10-20\%) depending on factors such as tree species, density of stand and age of stand, location, rainfall intensity; and evaporation during or after a rainfall event. Forest disruption, such as logging, forest fires and wind damage, etc., have major effects upon the canopy characteristics of forest stands and hydrological processes in watersheds. Where forest cover is permanently removed for the purposes of agriculture or urbanization, the hydrologic effects are more long lasting. This has obviously consequence on the quantity of ground water.

Remote sensing and Geographic Information Systems (GIS) have provided new tools for land cover mapping and change detection. The collection of remotely sensed data facilitates the synoptic analyses of earth-system function, patterning, and change at local, regional, and global scales over time.

\section{Characteristics of the Study Area}

Kagera River Basin relies entirely on Kagera River for its sustenance. Kagera River is found in East Africa; it rises from Burundi flowing through Rwanda, Uganda and Tanzania into Lake Victoria.Kagera River is the principal contributor of water to Lake Victoria which in turn is a source of the White Nile River.

The KRB occupies a highly strategic position with a surface area of $59,700 \mathrm{~km}^{2}$. Kagera River contributes 7.5 $\mathrm{km}^{3}$ of water per annum into Lake Victoria, the second largest freshwater lake in the world. The Kagera River has a length of $400 \mathrm{~km}$ with two headstreams of Ruvubu and Nyabarongo. The Ruvubu stream begins just from North of Lake Tanganyikain Burundi and the Nyabarongo stream begins from North-West Rwanda. These two main headstreams converge at Rusumo falls close to the Rwanda-Tanzania border, forming Kagera River which flows northwards along the border and then abruptly changing its course eastwards through lowland floodplains in Tanzania. Mwisa River joins the Kagera River just before the Kyaka Bridge in Tanzania (see Fig.2) while the Ngono River joins Kagera River at a confluence (Mbugano) just before the Kagera mouth at Kasensero in Uganda, where it enters Lake Victoria. The long term average water discharge of Kagera River to Lake Victoria is about $261 \mathrm{~m}^{3} / \mathrm{sec}$, flowing throughout the year.The spatial extent of KRB is as indicated in Figure 1 below

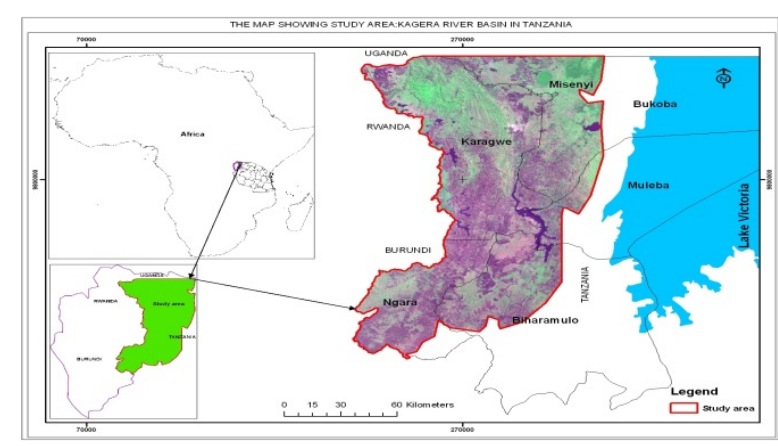

Figure 1. Kagera River Basin (source Lake Victoria Environmental Management Project Report, 2005) 


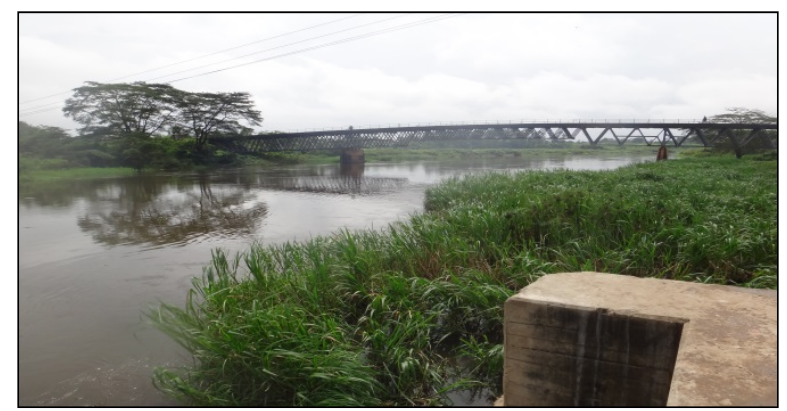

Figure 2. Kagera River at Kyaka Ferry in Tanzania

Socio-economic activities around KRB are; farming, wood logging, Fishing and Pastoralist. Farming accounts for more than $90 \%$ of the Basin's GDP and over $95 \%$ of population are employed by this sector (URT, 2004). The main food crops are Bananas, Sweet Potatoes, Cassava, Maize, Beans, Yams, Groundnuts, Finger Millet and Sorghum. Cash crops are mainly Coffee and Tea.

The main soil types in KRB are Ferralsols (red soils), Acrisols and Luvisols (sandy loam to clay loam soils), Gleysols and Planosols (clay soils), Andosols (volcanic soils)

There are two rainfall seasons; the longer one based on Southeasterly Monsoon winds bringing rain between about February and May and the shorter one based on Northeasterly Monsoon winds bringing rain from September to November. The Kagera River water runoff depends on the rainfall with a higher peak in May and smaller peak in November.

The Kagera River basin has elevation range of 1,200 to 1,600 amsl range. The rainfall is less than 1,000 mm over most of the Eastern half of the basin but it increases to over $1,800 \mathrm{~mm}$ to the West, where most of the runoff is generated.

It is estimated that around 14 Million people live in the KRB which is almost $40 \%$ of the population of people living in the entire Lake Victoria Basin. The population density within the KRB averages at 227 persons $/ \mathrm{km} 2$ compared to 174 persons $/ \mathrm{km}^{2}$ in the rest of the Lake Victoria basin.This is a testimony that KRB is highly populated. KRBis occupied by different ethnic tribes, namely; Haya, Nyankole, Nyambo, Tutsi, Hutu, Baganda, Shubi, Zinza, and Waha.

\section{Data and Methods Used}

In this study, primary and secondary data were used. Primary data included Landsat Satellite images of the years 1990, 2000 and 2011 and topographic maps covering the study area. Other primary data was from ground measurements, which was constituted by ground truth data. Secondary data used was water quantity and historical data of KRB. The Flowchart shown in figure 3 below summarizes the main activities carried out in this study. 


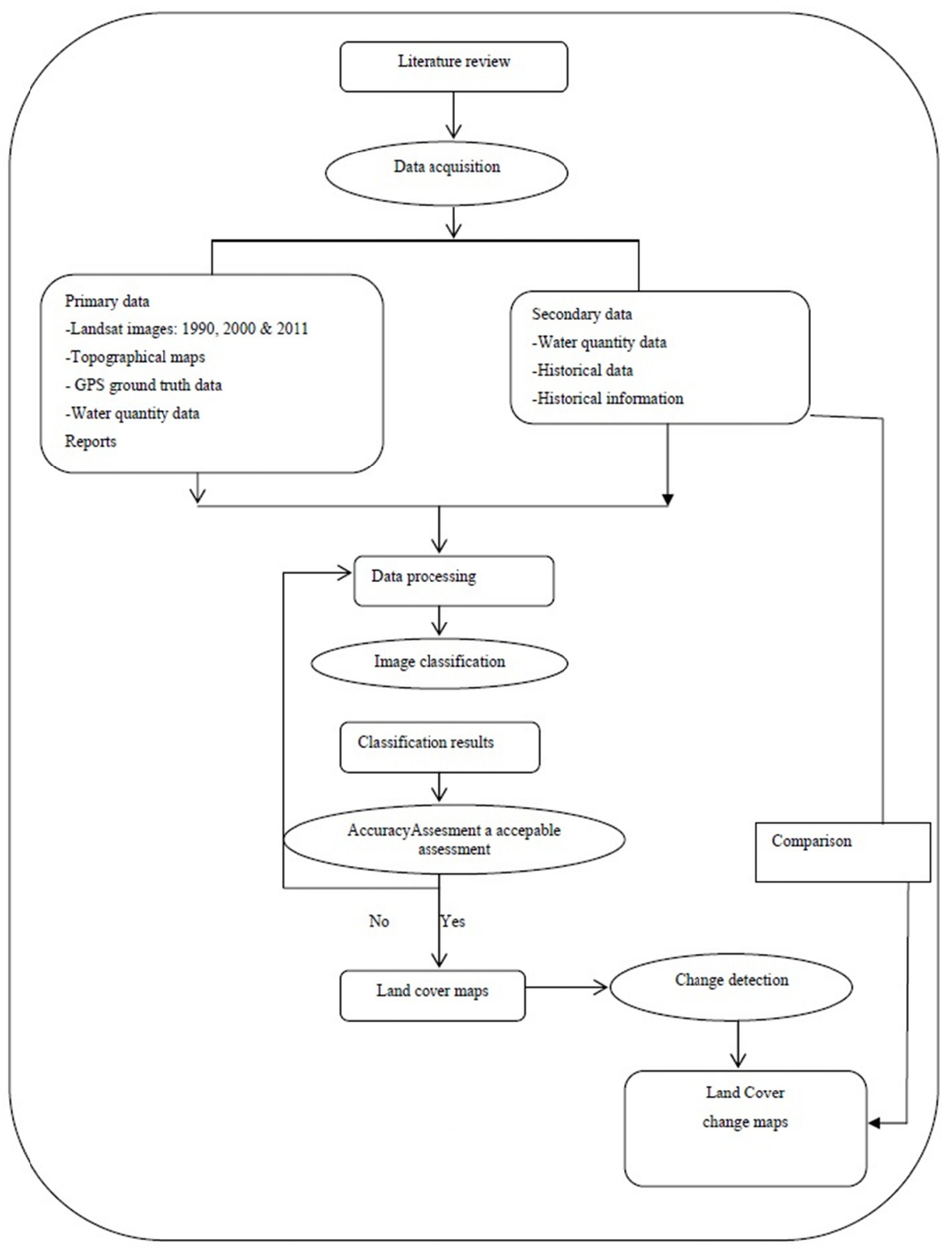

Figure 3. Major study activities

\subsection{Data Acquisition}

\subsubsection{Primary Data}

Primary data is basic the data for a study involving field work, taking the measurements or observations. Primary data used in this study are as stated in Section 2.0 above.It is noteworthy that ground truth data collected was used for image classification as well as for accuracy assessment of classification output.Hand held GPS Garmin 72 was used for this purpose.Additional information was obtained from interview from key informants particularly with regard to prevalent land uses in KRB. The major activity at this level was acquisition of satellite image data as well as topographical maps.As mentioned earlier, Landsat 5 TM images of 1990 and 2011 and Landsat $7 \mathrm{ETM}+$ of 2000 were used in this study. 


\subsubsection{Satellite Images}

The Landsat images were acquired based on availability, quality, resolution, seasonality, location, and objectives of the study.

Table 1. Details of landsat image scenes used in the study

\begin{tabular}{llll}
\hline S/No. & Satellite Sensor & WRS Path/Row & Date of acquisition \\
\hline 1 & Landsat 5 TM & $172 / 061,172 / 062$ & 20.07 .1990 \\
2 & Landsat 7 ETM+ & $172 / 061,172 / 062$ & 08.07 .2000 \\
3 & Landsat 5 TM & $172 / 061,172 / 062$ & 01.07 .2011 \\
\hline
\end{tabular}

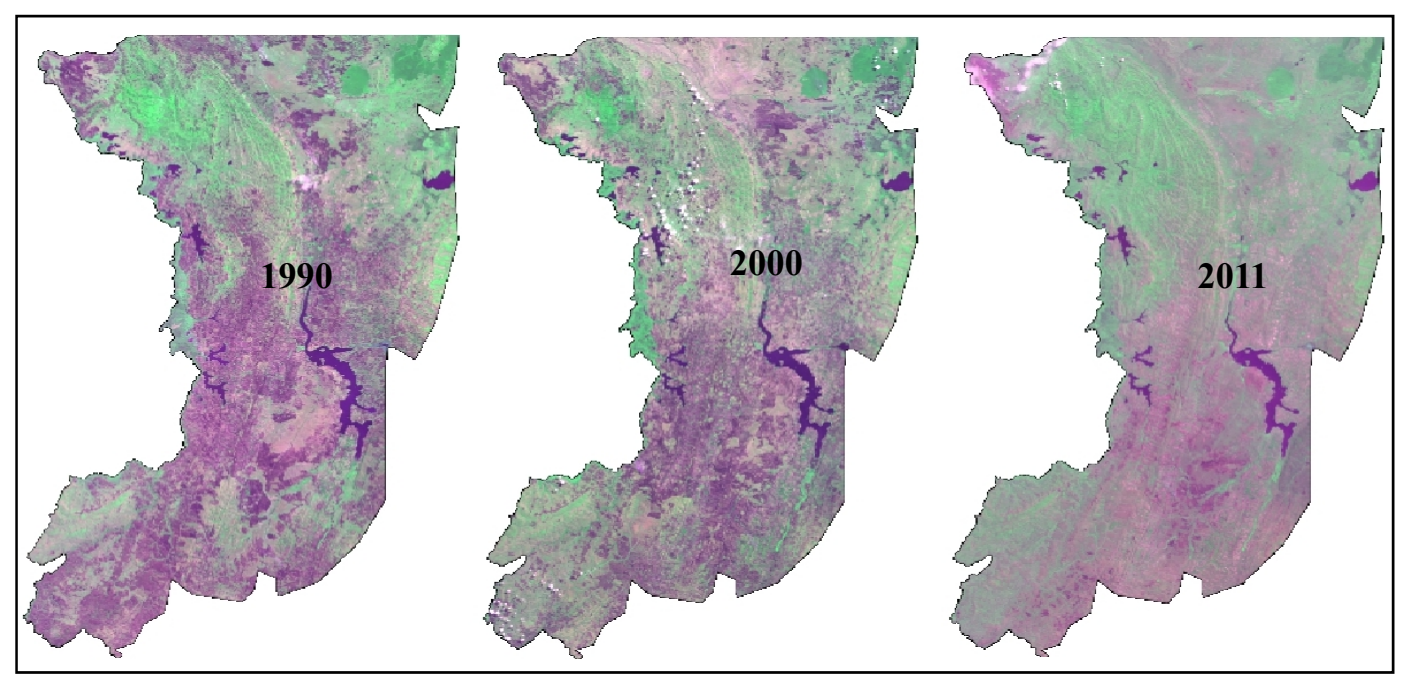

Figure 4. Landsat sub-images of 1990, 2000 and 2011 (Source: Author, 2011)

\subsubsection{Topographical Maps}

Topographical Standard Sheet map at scale of 1:50,000 acquired from the Surveys and Mapping Division of the Tanzania Ministry of Lands, Housing and Human Settlements were used as to ancillary data in data processing, analysis and interpretation of land cover classification results.

\subsection{Secondary Data}

This is either inferred or elicited data. In this study secondary data used was water quantity and historical data of $\mathrm{KRB}$,

\subsubsection{Water Quantity Data}

KRB water quantity data was obtained from Kyaka ferry hydrometric station (Lat. $1^{\circ} 15^{\prime}$ S, Long. $31^{\circ} 25^{\prime} \mathrm{E}$ ) as recorded by LVB office in Mwanza, Tanzania. Water quantity data were used for correlation with land cover changes in KRB between for the study period.

\subsection{Data Processing}

\subsubsection{Images Classification}

Image classification is the process of assigning real world labels to pixels vectors in a remotely sensed image. In image classification, pixels are classified according to their ground reflectance values measured by a satellite sensor. There are several ways of undertaking image classification, but the common ones are the Supervised, Unsupervised and Hybrid (combination of Supervised and Unsupervised) classification techniques

\subsubsection{Selection of a Classification Method}

In this study, Hybrid classification approach was opted for images classification. In Hybrid classification approach, features of both supervised and unsupervised classifications are utilized. Signatures from the 
unsupervised and supervised approach are appended together to form a single signature file which is used to classify the complete and full extent of the original image. Since the scope of this study was land cover analysis, a color composite image was formed for application in image in image classification by combining Band 4,5 and 3 which were assigned Red, Green and Blue colours respectively. Classification process was performed in ERDAS Imagine version 9.1 software Environment.

Following land cover types were identified: forests, woodlands, bush land, cultivated land, swamps, grasslands, bare lands, and urban areas. Then, land cover change maps were derived using image differencing method.

\subsubsection{The Accuracy Assessment of Image Classification Results}

Accuracy assessment determines the correctness of a classified image based on pixel groupings i.e. the categories of real world features presented. Accuracy assessment involves measuring the agreement between a classes that are assumed to be correct and those whose quality is unknown.In this study, the accuracy assessment was performed using a confusion matrix, in which classification results were compared with ground truth information as a test set.

\subsection{Land Cover Change Detection}

Change detection is a "process of identifying differences in the state of an object or phenomenon by observing it at different times". Land cover change detection requires multi-temporal data collected from a specific area for a given period of time and involves the use of these data sets to discriminate areas of land cover/use experiencing changes between the dates of imaging.

In this study, land cover change detection was performed through the overlay method based on generated vector themes of different years. The overlay was performed by intersecting of feature themes so that the boundaries and attributes of themes were integrated to form a composite or derivative output theme. Image differencing method was thereafter used to retrieve information characterizing the land cover change from multi-temporal images i.e. datasets of 1990-2000 and 2000-2011.

\subsection{Assessment of the Rate of Land Cover Change}

The estimation for the rate of change for the different land covers was computed based on the following formulae:

$$
\begin{aligned}
& \% \text { Cover change }=\frac{\text { Area }_{\text {iyear } x}-\text { Area }_{\text {iyear } x+1}}{\sum_{i=1}^{n} \text { Area }} \times 100 \\
& \text { Annual rate of change }=\frac{\text { Area }_{\text {iyear } x}-\text { Area }_{\text {iyear } x+1}}{t_{\text {years }}} \\
& \% \text { Annual rate of change }=\frac{\text { Area }_{\text {year } x}-\text { Area }_{\text {year }+1}}{\text { Area }_{\text {yearx }} \times t_{\text {years }}} \times 100
\end{aligned}
$$

Where: Area $_{\text {iyear } x}=$ area of cover $i$ at the first date,

Area $_{\text {iyear } x+1}=$ area of cover $\mathrm{i}$ at the second date,

$\sum_{i=1}^{n}$ Area $_{\text {i year } x}=$ total cover area at the first and

$t_{\text {years }}=$ period in years between the first and second scene acquisition data

\subsection{Analysis of Water Quality Data}

Water quantity data for year 1990, 2000 and 2011 were processed in Microsoft Excel application. Analysis was done by inferential statistics which was used to correlate land cover changes with water quantity. Kagera River water discharge into Lake Victoria vis-a'-vis land cover changes in KRB at respective times. Statistical analysis results are as shown in figure 5 below. 


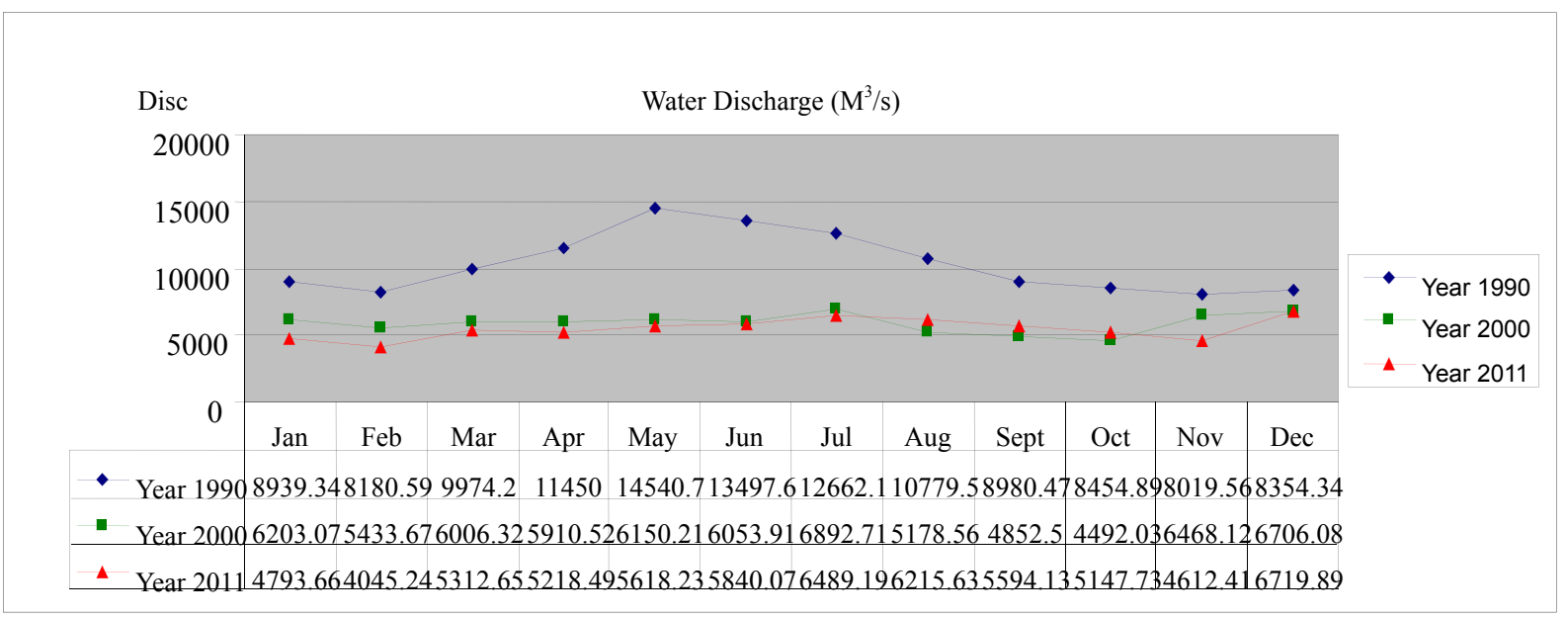

Figure 5. KRB Trend of Ground Water Discharge from Kagera River for the years 1990, 2000 and 2011

\section{Results and Analysis}

\subsection{Results}

4.1.1 LandCover Distribution over the Study Period

The land cover maps for 1990, 2000 and 2011 are as presented in Figure 3, 4 and 5 below.

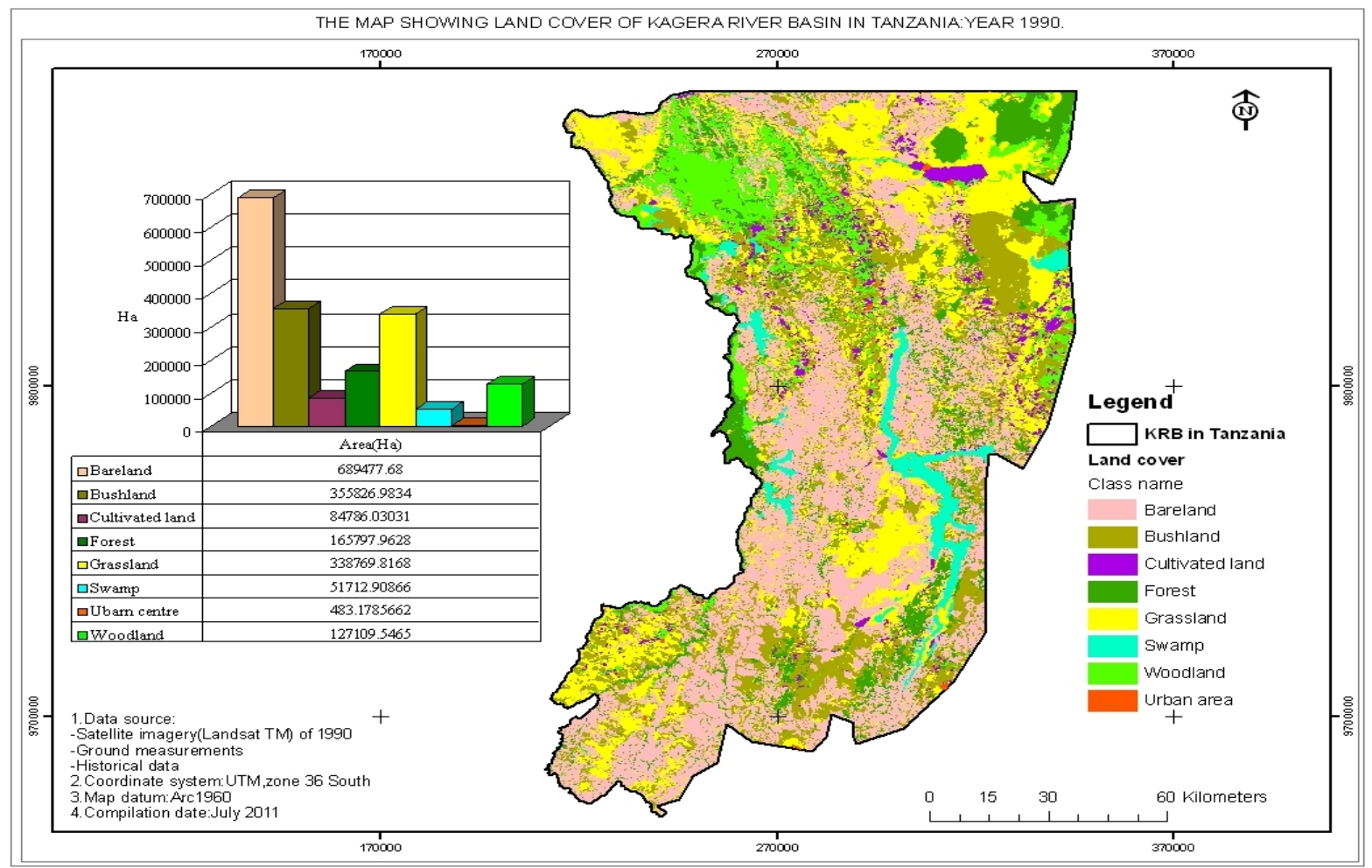

Figure 6. KRB classified land cover map of year 1990 


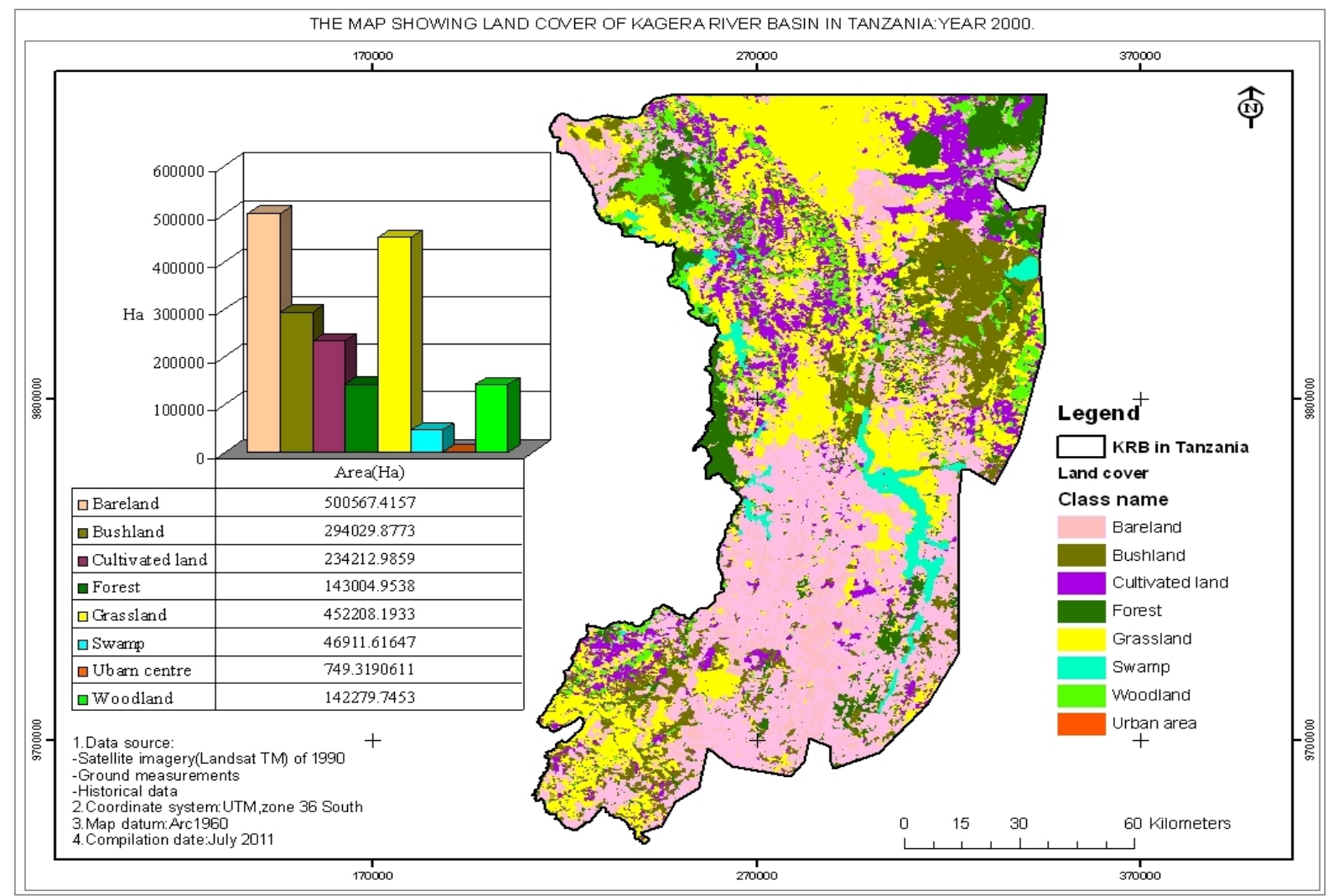

Figure 7. KRB classified land cover map of year 2000

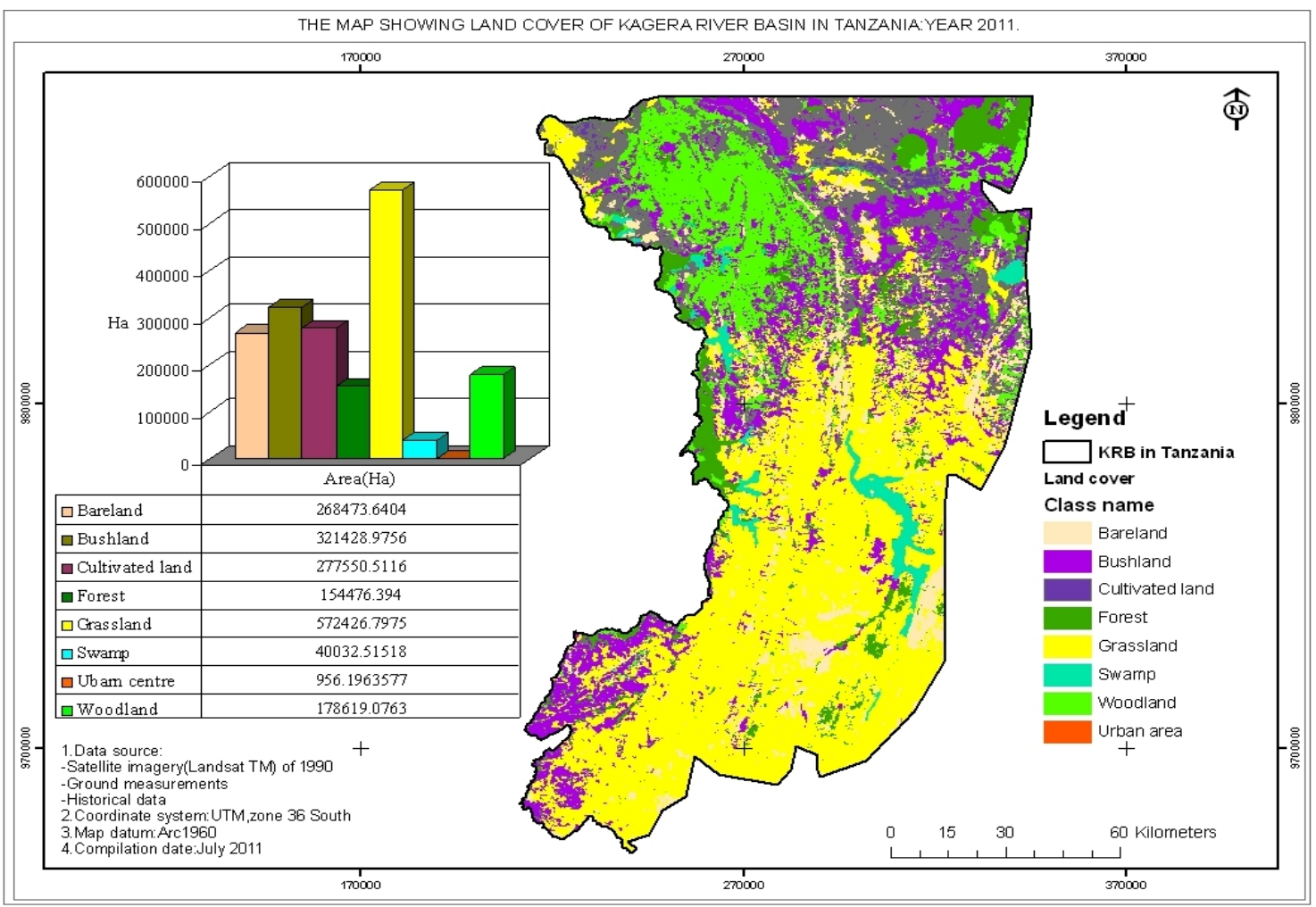

Figure 8. KRB classified land cover map of year 2011 


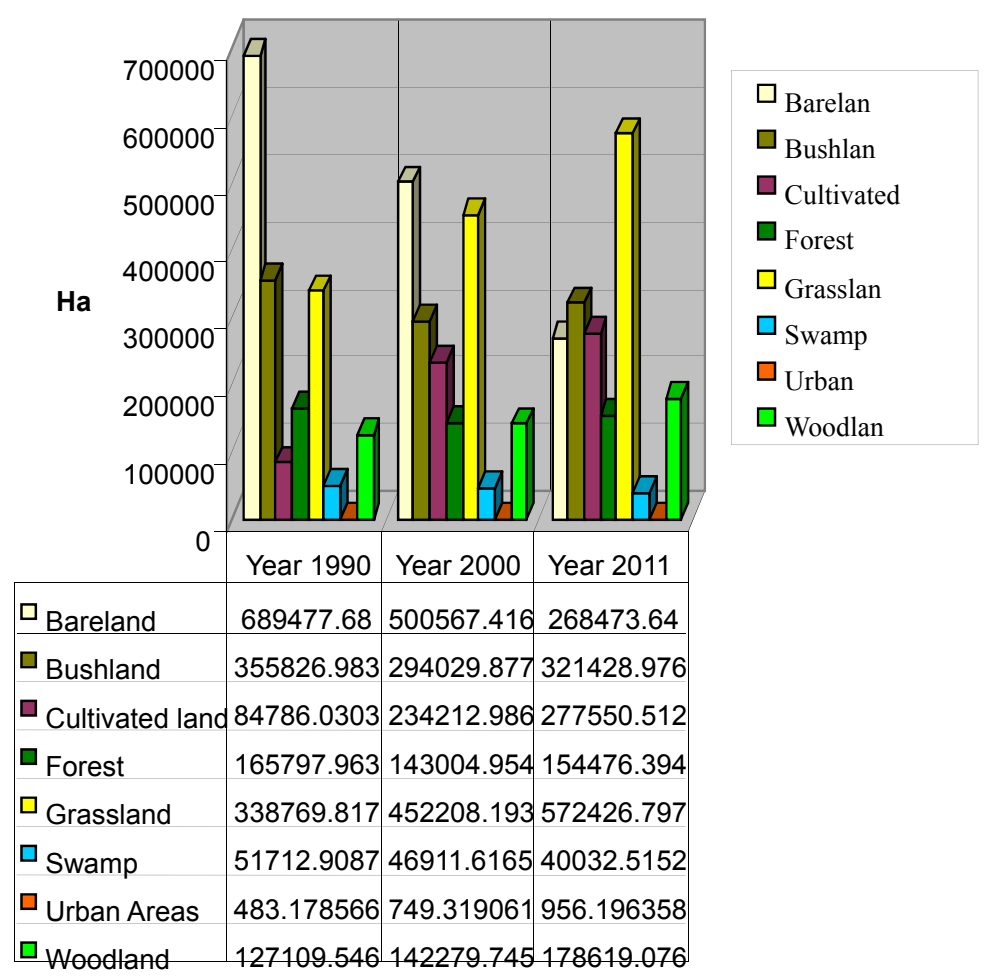

Figure 9. Land cover variations over the study period

\subsection{Results and Discussion}

\subsubsection{Land Cover Change over the Study Period}

The study results revealed a general decline of land cover in the study period.Specifically, forests, bush land and, bare land declined, whereas wood lands, cultivated areas increased, An, average decline rate of $8.5 \%$ ha per annum was noted.However, Forest areas demonstrated a relatively higher decline rate of $2 \%$. The area change and change rate of land-cover types are as summarized in tables 2 and 3.Owing to the fact that forests have ability of withholding ground water, it logical relating the decline in forests areas with quantity of Lake Victoria.

Table 2. Land cover change over period of over the study period

\begin{tabular}{|c|c|c|c|c|c|c|c|c|}
\hline \multirow[b]{2}{*}{ Cover class } & \multicolumn{2}{|c|}{ Land cover in 1990} & \multicolumn{2}{|c|}{ Land cover in 2000} & \multicolumn{4}{|c|}{ Change(Ha) } \\
\hline & $\begin{array}{c}\text { Area } \\
(\text { ha):1990 }\end{array}$ & $\begin{array}{c}\% \\
\text { cover }\end{array}$ & $\begin{array}{c}\text { Area } \\
(\text { ha):2000 }\end{array}$ & $\begin{array}{c}\% \\
\text { cover }\end{array}$ & $\begin{array}{c}\text { Area change } \\
\text { (ha) }\end{array}$ & $\begin{array}{c}\text { \% Cover } \\
\text { change }\end{array}$ & $\begin{array}{c}\text { Annual rate of change } \\
\text { (ha/yr) }\end{array}$ & $\begin{array}{c}\text { \% Annual rate of change } \\
(\% / y r)\end{array}$ \\
\hline Bareland & 689477.680 & 38.009 & 500567.416 & 27.595 & -188910.264 & -10.414 & -18891.026 & -3.774 \\
\hline Bushland & 355826.983 & 19.616 & 294029.877 & 16.209 & -61797.106 & -3.407 & -6179.711 & -2.102 \\
\hline $\begin{array}{l}\text { Cultivated } \\
\text { land }\end{array}$ & 84786.030 & 4.674 & 234212.986 & 12.912 & 149426.956 & 8.238 & 14942.696 & 6.380 \\
\hline Forest & 165797.963 & 9.140 & 143004.954 & 7.884 & -22793.009 & -1.257 & -2279.301 & -1.594 \\
\hline Grassland & 338769.817 & 18.676 & 452208.193 & 24.929 & 113438.377 & 6.254 & 11343.838 & 2.509 \\
\hline Swamp & 51712.909 & 2.851 & 46911.616 & 2.586 & -4801.292 & -0.265 & -480.129 & -1.023 \\
\hline Urban areas & 483.179 & 0.027 & 749.319 & 0.041 & 266.140 & 0.015 & 26.614 & 3.552 \\
\hline Woodland & 127109.546 & 7.007 & 142279.745 & 7.844 & 15170.199 & 0.836 & 1517.020 & 1.066 \\
\hline Total area & 1813964.107 & 100 & 1813964.107 & 100 & & & & \\
\hline
\end{tabular}


Table 3. Land cover change over period of 2000-2011

\begin{tabular}{|c|c|c|c|c|c|c|c|c|}
\hline \multirow{2}{*}{ Cover class } & \multicolumn{2}{|c|}{ Land cover 2000} & \multicolumn{2}{|c|}{ Land cover 2011} & \multicolumn{4}{|c|}{ Change(Ha) } \\
\hline & Area $(h a): 2000$ & $\%$ cover & Area (ha):2011 & $\%$ cover & Area change (ha) & $\%$ Cover change & Annual rate of change (ha/yr) & Annual rate of change (\%/yr) \\
\hline Bareland & 500567.416 & 27.595 & 268473.640 & 14.800 & -232093.775 & -12.795 & -21099.434 & -7.859 \\
\hline Bushland & 294029.877 & 16.209 & 321428.976 & 17.720 & 27399.098 & 1.510 & 2490.827 & 0.775 \\
\hline Cultivated land & 234212.986 & 12.912 & 277550.512 & 15.301 & 43337.526 & 2.389 & 3939.775 & 1.419 \\
\hline Forest & 143004.954 & 7.884 & 154476.394 & 8.516 & 11471.440 & 0.632 & 1042.858 & 0.675 \\
\hline Grassland & 452208.193 & 24.929 & 572426.797 & 31.557 & 120218.604 & 6.627 & 10928.964 & 1.909 \\
\hline Swamp & 46911.616 & 2.586 & 40032.515 & 2.207 & -6879.101 & -0.379 & -625.373 & -1.562 \\
\hline Urban centre & 749.319 & 0.041 & 956.196 & 0.053 & 206.877 & 0.011 & 18.807 & 1.967 \\
\hline Woodland & 142279.745 & 7.844 & 178619.076 & 9.847 & 36339.331 & 2.003 & 3303.576 & 1.850 \\
\hline Total area & 1813964.107 & 100 & 1813964.107 & 100 & & & & \\
\hline
\end{tabular}

During 2000-2011 period, Forests increased by $0.6 \%$, Woodland increased by $2 \%$, Bush land increased by $1.5 \%$, Cultivated land increased by $2.4 \%$, Grassland increased by $6.6 \%$, Urban areas alomost remained constant, Bare land decreased by $12.8 \%$ and Swamps decreased by $0.4 \%$.

\subsubsection{Hydrological Flow}

Hydrological investigations showed that river flow regimes changed between 1990-2000 and 2000-2011 due to land cover dynamics caused by human activities. The perceived drivers for the changes include; shifting cultivation, agricultural expansion, wildfires and demand for forest products (mainly timber, charcoal, firewood, poles etc), climate changes.

\section{Conclusions}

Results revealed a decline of forest areas in KRB from 1990 to 2011. The results further revealedthat cultivated land, increased in the in the study period, whereas bare land and swamps/water areas decreased during the same period. As ground water occurrence is dependent on such factors as rock types, land forms, geological structures, soil type, land use, precipitation etc. Amongst the above factors, land use is relatively more dynamic than others. As such, the observed decline in forest areas entails a direct proportional decline of ground water flowing from Kagera river into Lake Victoria.

The observed land cover changes were attributed to socio-economic factors including but not limited to lack of environmental knowledge, uncontrolled population growth, deforestation and rural-migration phenomena, typical of developing countries. It is recommended that in order to ensure sustainability of KRB as base support for Lake Victoria water regime, following ought to be done b: y responsible authorities

i. Practice effective land use planning by communities neighboring Lake Victoria in order to reduce human pressure on the natural resources thereof.

ii. Establish and enforce community by-laws which would build sustainable natural resources usage within KRB.

iii. Implement regular KRB Community awareness and sensitization on environmental conservation.

\section{References}

Bhatta, B. (2011). Remote sensing and GIS (2nd ed.). Oxford University Press.

Briassoulis. (2000). Analysis of Land use Change: Theoretical and Modelling Approaches. Regional Research institute, West Virginia University.

Kashaigili, J. J. (2008). Impacts of land-use and land-cover changes on flow regimes of the Usangu wetland and the Great Ruaha River, Tanzania. Physics and Chemistry of the Earth, 33, 640-647. https://doi.org/10.1016/j.pce.2008.06.014

Leduc, C., Favreau, G., \& Scherueter, P. (2001). Long-term rise in Sahelian water-table the continental terminal in South-West Niger. Journal of Hydrology, 243, 43-54. https://doi.org/10.1016/S0022-1694(00)00403-0

Lillesand, T. T., \& Kiefer, R. W. (2004).Remote sensing and image Interpretation (4th ed.). John Willey and Sons, Including USA. 
Mather, P. M. (1999). Computer Processing of Remotely Sensed Images. John Wiley \& Sons Ltd, England.

Meyer, W. B., \& Turner, B. L. (1996). Land use and Land cover changes for Geographers. Geojournal, 39(3), 237-240. https://doi.org/10.1007/BF00188373

Mutie, S. M. (2006). Land cover change effects on flow regime of Mara River, Proceedings of the $2^{\text {nd }}$ International ISCAM Conference(B. Van de Walle and B. Carle, eds. Brussels, Belgium.

Ojima, D. S. (1994). The Global impact of land use changes.Bioscience, 44, 300-311. https://doi.org/10.2307/1312379

Richards, S. J. (1990). Land Transformation in: The Earth as transformed by human actions. Cambridge University Press, New York, pp 163-178.

Riebsame, W. E., Meyer, W. B., \& Turner, B. L. II. (1994).Modelling Land use and cover as part of global Environmental changes, climate changes. Climate Change, 28, 45. https://doi.org/10.1007/BF01094100

Singh, A. (1989). Digital Change Detection Techniques using Remotely Sensed Data. International Journal of Remote Sensing, 10(6), 986-1003. https://doi.org/10.1080/01431168908903939

Sutcliffe, J. V., \& Parks, Y. P. (1999). The Hydrology of Nile River. Wallingford: IAHS Press Special Publication No.5.

Vanacker, V. (2002), Geomorphic Respond to Human-Induced Environmental change in Tropical Mountainous Areas, The Austo Ecuadorian as a case study, Doctoral thesis, Katholic University of Leuven, pp 111-119.

Wilkie, D. S., \& Finn, J. T. (1996). Remote Sensing Imagery for Natural Resources Monitoring. Columbia University Press, New York, P295.

Zhou, S. Q., Li, B., \& Sun, B. (2008). Modeling Spatial -temporal pattern of land -use changes using Multi-temporal remotely sensed imagery.

\section{Copyrights}

Copyright for this articleis retained by the author(s), with first publication rights granted to the journal.

This is an open-access article distributed under the terms and conditions of the CreativeCommons Attribution license (http://creativecommons.org/licenses/by/4.0/). 